\title{
HISTORICAL MILESTONES IN THE DEVELOPMENT OF PRESCHOOL EDUCATION IN THE RUSSIAN FEDERATION
}

\author{
(C) Zhanna Kh. Baskaeva, Fatima Ch. Tatrova \\ North Ossetian State University after K.L. Khetagurov, \\ Vladikavkaz, Russian Federation \\ zhanna-64@mail.ru
}

In the course of evolutionary historical development in Russia, the national education system has been built and it is developing, including preschool, school, multi-level professional and additional education. Preschool education in the modern Russian Federation is understood as education, training and development, as well as supervision, care and rehabilitation of children of preschool age from 2 months to 7 years. According to the analytical report of the international audit and consulting company FinExpertiza, in 2019 $78.9 \%$ of Russian babies (4.1 million children) under the age of 3 years did not attend a day nursery. At the same time, the largest share of babies under the age of 3 years who do not attend nurseries is recorded, according to the study, in the Republic of Ingushetia. Here, $96.59 \%$ of toddlers stay with their mothers, and only 800 out of 23,492 children of the republic under the age of 3 visit the nursery. This figure is slightly lower in the Republic of Dagestan. Here $94.22 \%$, or 139,205 babies stayed at home, and 8540 babies go to the nursery. In third place is the Republic of Crimea, in which $91.13 \%$ of toddlers are with their parents at home, and only $8.87 \%$, or 5,665 kindergarten children attend. Given the fact that in Russia now more than a third of young families with a child are not provided with preschool institutions, and in the south of Russia these statistics are even higher, preparing parents for the basics of family preschool education is becoming one of the most important tasks of youth family policy. It is obvious that the system of preschool education, like the entire system of relations in the field of education and upbringing of the younger generation, is influenced by powerful civilizational and technological trends, which often destroy historical features and national traditions. In this regard, the study of the characteristics of the national education system in its historical evolution is of particular relevance and significance.

Key words: Friedrich Froebel's philosophy, the Soviet system of preschool education, the Federal state educational standard for preschool education, development of education in 2013-2020.

\section{[Ж.Х. Баскаева, Ф.Ч. Татрова Исторические вехи развития дошкольного образования в Рос- сийской Федерации]}

В ходе эволюционного исторического развития в России выстроена и развивается национальная система образования, включая дошкольное, школьное, многоуровневое профессиональное и дополнительное образование. Дошкольное образование в современной Российской Федерации понимается как воспитание, обучение и развитие, а также присмотр, уход и оздоровление детей дошкольного возраста от 2 месяцев до 7 лет. Согласно данным аналитического доклада международной аудиторско-консалтинговой компании FinExpertiza, в 2019 году 78,9\% российских детей $(4,1$ млн.) в возрасте до 3 лет не посещали ясли. При этом самая значительная доля малышей в возрасте до 3 лет, не посещающих ясли, зафиксирована, согласно результатам исследования, в Республике Ингушетия. Здесь с мамами остаются 96,59\% детей ясельного возраста, а посещают ясли всего 800 из 23 492 детей республики в возрасте до 3 лет. Чуть ниже эта цифра в Республике Дагестан. Здесь 94,22\%, или 139205 малышей остались дома, в ясли здесь ходят 8540 малышей. На третьем месте Республика Крым, в которой 91,13\% детей ясельного возраста находятся с родителями дома, и лишь $8,87 \%$, или 5665 детей ясли посещают. С учётом того обстоятельства, что в России сейчас более трети молодых семей, имеющих ребёнка, не обеспечены детскими дошкольными учреждениями, а на Юге России эта статистика еще выше, подготовка родителей к азам семейного дошкольного воспитания становится одной из важнейших задач молодёжной семейной политики. Очевидно, что система дошкольного воспитания, как и вся система отношений в области образования и воспитания подрастающего поколения, находится под влиянием мощных цивилизационных и технологических трендов, нередко разрушающих исторические особенности и национальные традиции. В этой связи изучение особенностей национальной системы образования в его исторической эволюции приобретает особую актуальность и значимость. 
Ключевые слова: философия Фридриха Фробеля, советская система дошкольного образования, Федеральный государственный образовательный стандарт дошкольного образования, развитие образования в 2013-2020.

Zhanna Kh. Baskaeva - Ph.D. in Pedagogy, Associate Professor, North Ossetian State University after K.L. Khetagurov, Vladikavkaz, Russian Federation.

Fatima Ch. Tatrova - student, North Ossetian State University after K.L. Khetagurov, Vladikavkaz, Russian Federation.

Баскаева Жанна Хасанбековна - кандидат педагогических наук, доцент, Северо-Осетинский государственный университет имени К.Л. Хетагурова, Владикавказ, Российская Федерация.

Татрова Фатима Черменовна - студентка, Северо-Осетинский государственный университет имени К.Л. Хетагурова, Владикавказ, Российская Федерация.

Preschool education in Tsarist Russia. The first pre-school institutions in Russia of the royal period began to appear in major cities such as Moscow and St. Petersburg in the 1860-70s. It should be noted that new types of educational institutions for pre-school children appeared in Western Europe a little earlier. The first free, "people's kindergarten" in Russia for children of citizens from lower strata of the population was opened in 1866 under the charitable "Society of Cheap Apartments" in St. Petersburg. In the same year A. S. Simonovich opened a paid private kindergarten for children of intellectuals [3]. Thus, two types of pre-school institutions appeared in Russia almost simultaneously: private, serving mainly wealthy families, and free, intended for children of working mothers. The latter were inexpensive and they were managed by charitable foundations. In addition to free kindergartens, charitable foundations in Moscow and St. Petersburg organized many free grounds, shelters and hotbeds for children of lower strata of the population, as well as for orphans.

In the same years the method of pre-school education arose. The first journal, where systematic notes on forms and methods of education of children of pre-school age were published, became "Kindergarten" edited by A. Simonovich. It should be noted that the authority of the edition was quite high, as evidenced by the participation of K. D. Ushinsky in its work and publication.

It is important to note that unlike primary and secondary schools, pre-school institutions were not controlled by the Ministry of Education and therefore had a wide variety of formats and educational approaches. The philosophy of education that inspired the pioneers of Russian preschool education was the philosophy of Friedrich Froebel. The first St. Petersburg Froebel society for the promotion of the initial upbringing of preschool children was established in 1871 . The Society promoted the opening of courses to train female educators in families and kindergartens, as well as lectures on preschool education. And five years later similar societies were organized in different cities of the empire, which held courses lasting a season, a year and three years [7]. In 1908, the Froebelev Institute was opened in Kiev with a three-year course of pedagogical training of gardeners, which also organized pedagogical and psychological laboratories and kindergartens, where students could have practical training [8].

The Froebelian approach, in which teachers of young children were compared to gardeners caring for plants, left its mark in today's Russian preschool education, because the education and upbringing institution for young children is still called kindergarten. And Froebel societies played an important role in teaching preschool teachers and teaching parents early development and education [7].

At the beginning of the 20th century the so-called home kindergartens appeared, the children were brought to the apartments of project participants in turn, and parents them- 
selves acted as educators. In 1908 there were 16 such kindergartens in St. Petersburg. There had been 19 pre-school institutions in major cities and 343 seasonal nurseries in rural areas by 1913. Since a large family in Russia is very common, most young children were under the care of family members. There had been 150 kindergartens for 4,000 children in the country by 1914. In 1913-1917, the Vice-President of the St. Petersburg Society for the Promotion of Preschool Education was the famous Russian teacher Elizabeth Ivanova Tikheeva, who studied didactics and methods of primary education. Since 1913, she had been running the kindergarten established under the Society for the Promotion of Preschool Education, which she had been running from 1917 till 1928. In Russia the number of kindergartens had increased to 280 by 1917 [1].

As the number of pre-school institutions grew, there was an increasing need to develop theoretical foundations for early education compatible with Russian culture and with values of Russian society. Many of Russia's leading intellectuals, from educators to psychologists and doctors, have contributed to the creation of such a fund, but not all of their work has had the same impact on the development of preschool education in the following decades.

Soviet preschool education system. The State system of pre-school education in Russia began after the adoption of "the Declaration on Pre-school Education" on the 20th of December, in 1917. This document defined the principles of Soviet pre-school education: free and accessible social education of children of pre-school age.

In 1918 on the basis of the Moscow Higher Women's Courses on the initiative of Professor K. N. Kornilov the second Moscow State University was opened where the pedagogical faculty with pre-school department was organized.

The number of pre-school institutions grew rapidly, from 400 in 1918 to 4,723 in two years. The number of their pupils had increased to 250,000 [8].

The first All-Russian Congress on Pre-school Education, held in Moscow in 1919, was an important milestone in the creation of the State system of training of teachers of pre-school education.

Calls for universal day childcare were mainly the result of new labour laws in postrevolutionary Russia and in other USSR republics requiring work outside the house for all women, including mothers of young children. Soviet ideologists also defended the idea of childcare in non-family settings as the most compatible with the prevailing Leninist views on institutional education, which is favorable for the development of collectivist values and behaviour.

From the beginning, Soviet pre-school institutions were considered as providing childcare and education for young children. Before the introduction of the first national preschool curriculum guides in 1932, preschool teachers had used various educational approaches, including a project approach, open learning, and free play. Since 1932 subsequent iterations of the national preschool program aimed to ensure continuity between preschool and primary education, which required preschool teachers to follow a certain volume and sequence of specific skills and concepts which were to prepare children for school. Another trend in Soviet preschool education, which has been seen since the 1930s, was a growing focus on teacher-oriented activities. The focus is on child choice and free play. The Standard Kindergarten Education Program (Standard Preschool Education Program) has been published [9].

The first "Kindergarten Work Program" was published in 1934, and the "Kindergarten Charter" was published in 1938, defining the tasks, structure and peculiarities of the functioning of pre-school institutions, and the "Kindergarten Teachers Manual" which contained methodological instructions on the sections of work with children. According to the special 
decree of the Soviet Union departmental kindergartens were introduced in 1937, and model states for kindergartens of all kinds and departments were established in 1939 [3].

In 1928 the monthly scientific and methodological journal "Preschool Education" began to be published.

In 1937 the resolution of the Soviet Union gave a green light to the creation of departmental kindergartens at factories and large enterprises, which allowed to expand the sources of financing of pre-school education and bring it closer to production. At the same time, there was a form of early care for children, a nursery, where babies were taken starting from 2 months, that is, at the end of maternity leave of the mother. To continue breastfeeding mothers were granted paid special breaks during the working day [9].

In 1939 model staff states were established for the kindergartens of each type and departmental affiliation. By 1940 more than two million pupils had been covered by public education. The surge in the number of places in kindergartens was caused by the Great Patriotic War. By 1945 the number of kindergartens had been increased to 25 thousand, compared to 14.3 thousand in 1941 [8].

After the war, the development of the system of public pre-school education continued, which was also driven by the need to involve women in the economy destroyed by the war and to provide them with conditions for education and career development.

In 1959 there was a new type of pre-school educational institution, preprimary school, where, at the request of parents, children could be raised from two months to seven years. This was due to the need to improve the organization of pre-school institutions and, in particular, to establish continuity in the upbringing of early and pre-school children.

In 1964 a comprehensive kindergarten education program was established, which became a single compulsory document in the work of pre-school institutions in the country. Leading research institutes of pre-school education of academy of pedagogical sciences of the USSR and leading departments of pre-school pedagogy worked on the program. In 1978 after making further changes, the program was named the Model. It lasted until 1984, when it was replaced by the Model Kindergarten Education and Training Program [3].

In connection with the reform of the education system, the Concept of Preschool Education emerged on the threshold of the 1980s and 1990s [6]. It highlights four basic principles, which are fundamental for the expert assessments of Russian preschool education:

- Humanization - education of humanistic orientation of pre-school personality, civic, hard work, respect for human rights and freedoms, love for family, Motherland, nature;

- Developmental nature of education - orientation towards the child's personality, preservation and promotion of his health, setting on mastery of ways of thinking and activity;

- Individual approach to education and training - development of the child in accordance with his or her tendencies, interests, abilities and capabilities;

- Deideologization of preschool education - priority of universal human values, rejection of ideological orientation of content of kindergarten educational programs [9].

Preschool education in modern Russia. After the collapse of the USSR and the subsequent economy's plunge, the system of pre-school education declined sharply, primarily at the expense of departmental kindergartens: the social load was a burden for privatized enterprises. The vacated premises were sold or rented. As a result of such ill-conceived policies, the system of pre-school education has been in deep crisis in ten years: not only the number of pre-school education institutions has decreased dramatically, but also their financing, that in turn has led to the decline of the material base of the state system of preschool education of Russia. In general, the financing of state pre-school institutions of new 
Russia significantly lagged behind the Soviet standards: the salary of pedagogical workers was low, the equipment was not updated.

At the same time, since the early 1990s, pre-school institutions in the commercial sector of Russia have begun to appear and develop actively. Most non-State pre-school institutions were established on a fee-paying basis at private secondary schools and were designed for the well-off segment of the population, remaining poorly accessible for lowincome families. To a certain extent, the shortage of places in free state pre-school institutions against the background of weak state policies of support of family and motherhood led to the fall in the birth rate, depopulation of the Russian population in the mid-2000s. After the financial and economic crisis of 2007-2008 the number of families with incomes below the subsistence minimum began to grow steadily, the birth of the second child and the third child became a disabling burden of the average Russian family. More than 2 million children were on the waiting list for a place in the kindergarten in 2012 [14].

The situation has begun to change since 2010. In 2012 the Federal Law "On Education in the Russian Federation" was adopted, according to which all children between the ages of 2 months and 8 years are guaranteed access to the State preschool institution. The adopted Federal State Educational Standard of Preschool Education in 2013 is aimed at combining the best features of the existing system with the representation of young children as agents of their own development. [11]. The State Program of the Russian Federation "Development of Education in 2013-2020" provided for the formation of a qualitative subject-development environment in pre-school institutions and an effective system of psychological and pedagogical expertise of the educational process for the development of the abilities of each child. The goals, objectives and subject of preschool education are described in the Federal State Standard adopted for the first time in Russian history [11, 12].

Changes in population policies, and especially the maternal capital program have contributed to the increase in fertility, that has led to a shortage of kindergarten places even though most women have benefited from parental leave up to the age of 3 .

Construction of new kindergartens, including departmental kindergartens, has begun. In 2018 the number of preschool institutions reached 46,000, they are visited by more than 6 million children, and by the end of 2019 it is planned to create 90,749 additional places only for children between the ages of 2 months and 3 years [2].

The Federal State Educational Standard sets the following objectives for preschool education in the Russian Federation:

- Social status of preschool education has been raised.

- The State ensures equal opportunities for all children to have access to high-quality preschool education.

- The State ensures that all preschool institutions across the country meet the same program standards.

- All pre-school institutions of the Russian Federation continue to create a single educational space.

The Federal State Educational Standard also defines tasks for preschool institutions:

- To preserve and to promote the health and well-being of children, including emotional well-being.

- To guarantee equal opportunities for development for all young children, regardless of their place of residence, sex, ethnicity, language, social status, health and other individual characteristics.

- To ensure continuity between preschool and primary education for their purposes and their content. 
- To enable all children to develop according to their age and individual abilities and interests.

- To integrate cognitive and non-cognitive learning into a comprehensive educational system based on societal norms and values.

- To develop comprehensively developed people by promoting healthy lifestyles, promoting physical, cognitive, moral and social development, developing initiative and responsibility, and laying the foundation for the readiness to school.

- To provide a range of educational programs and teaching methodologies to meet the needs of different students.

- To create a sociocultural environment suitable for children of different ages, levels of development and individual needs.

- Psychological and educational support for families; training of parents on topics related to the health and development of the child.

Finally, the Federal State Education Standard defines the basic principles governing education policy as well as classroom practice:

- Children have to be able to realize completely unique opportunities and advantages of all three stages of the early childhood (infancy, baby age and preschool age); Their development at these stages must be strengthened and never accelerated.

- The instruction should take into account the individual characteristics and preferences of children, so that children play an active role in choosing the content of their education.

- Adults and children participate in interaction in the classroom as partners.

- Children's initiative is encouraged.

- Pre-school institutions establish and maintain partnerships with families.

- Children learn about sociocultural norms and traditions of their families, communities and the State. activities.

- Children develop learning skills and motivation to learn by participating in various

- Teaching practices and expectations used by pre-school educators are appropriate to the level of development and meet the needs of individual children.

- Account is taken of the ethnocultural situation of children's development.

The introduction of the Federal State Educational Standard has had a profound impact on the development and adoption of new models for the education and upbringing of children in kindergartens, as well as on the development of quality criteria for the evaluation of educational programs. However, it should be recognized that all these processes need organizational and methodological support, public assessment and necessary financing in order to achieve the goals of the State Program of the Russian Federation "Development of Education in 2013-2020" and to meet the requirements of the Federal State Educational Standard of pre-school education in the Russian Federation.

\section{Лumepamypa}

1. Баландина A. «Фабрика по шлифовке»: зачем России детские сады / Газета.Ru [Электронный ресурc]. URL: https://www.gazeta.ru/social/2018/09/25/11997355.shtml (дата обращения 17.12.2019 г.)

2. Баскаева Ж.Х. Выпускающая кафедра как основной элемент образовательного процесса по подготовке педагогических кадров в условиях университета/ ПМНО: Поиск. Мастерство. Новаторство. Опыт Материалы региональной научнопрактической конфреренции. 2009. С. 16-24. 
3. Бодрова Е. В., Давыдов В.В., Петровский В.А., Стеркина Р.Б. Опыт построения психолого-педагогической концепции дошкольного воспитания // Вопросы психологии. 1998. № 2.

[Электронный ресуpc].URL: http://www.voppsy.ru/issues/1989/893/893022.htm (дата обращения 19.12.2019 г.)

4. Гуриева Л.К. Эволюция представлений о социальной ответственности бизнеса // Современные корпоративные стратегии и технологии в России. Сборник научных статей: В 3 Ч. М., 2016. С. 87-92.

5. Гуриева Л.К., Нурмагомедов А.А. Социальная ответственность бизнеса: истоки и современные представления // Гуманитарные и социально-экономические науки. 2016. № 3 (88). С. 152-154.

6. Давыдов В.В., Кудрявцев В.Т. Развивающее образование: теоретические основания преемственности дошкольной и начальной школьной ступеней // Вопросы психологии. 1998. № 2.

URL: http://www.voppsy.ru/journals_all/issues/1997/971/971003.htm (дата обращения 19.12.2019 г.)

7. Дошкольная педагогика / под ред. В.И. Ядешко, Ф.А. Сохина. М.: Просвещение, 1978. 429 c.

8. История дошкольного образования в России. / Activityedu.ru [Электронный ресурс]. URL: https://activityedu.ru/Blogs/preschool/my-prihodim-v-detskiy-sad/ (дата обращения 16.12.2019 г.)

9. История дошкольной педагогики / М.Ф. Шабаева, В.А. Ротенберг, И.В. Чувашев / под ред. Л.Н. Литвина. М.: Просвещение, 1989.

10. Крулехт М.В., Тельнюк И.В. Экспертные оценки в образовании: учебное пособие для студ. фак. дошкольного образования высш. пед. учеб. заведений. М.: Издательский центр «Академия», 2002. 112 с.

11. Постановление Правительства РФ от 15 апреля 2014 г. № 295 «Об утверждении государственной программы Российской Федерации «Развитие образования» на 2013 - 2020 годы» (с изменениями и дополнениями) (утратило силу). Постановление Правительства РФ от 15 апреля 2014 г. № 295 «Об утверждении государственной программы Российской Федерации «Развитие образования» на 2013 2020 годы».

12. Приказ Министерства образования и науки Российской Федерации (Минобрнауки России) от 17 октября 2013 г. № 1155 «Об утверждении федерального государственного образовательного стандарта дошкольного образования».

13. Федеральный закон «Об образовании в Российской Федерации» № 273-Ф3 от 29 декабря 2012 года.

14. Ясли за полмиллиона: создание 1 «ребенко-места» для самых маленьких обойдется бюджету более чем в 500 тыс. рублей / FinExpertiza.ru [Электронный ресурс]. URL: https://finexpertiza.ru/press-service/researches/2019/yasli-polmilliona/?sphrase_id=9047 (дата обращения 06.01.2020 г.)

15. Gurieva L.K. New strategic approach to the innovative development of regions // Научный альманах стран Причерноморья. 2016. № 2 (6). С. 1-4.

\section{References}

1. Balandina A. "Fabrika po shlifovke": zachem Rossii detskie sady / Gazeta.Ru ["Grinding factory": why does Russia need kindergartens. Gazeta.Ru]. Available at: https://www.gazeta.ru/social/2018/09/25/11997355.shtml (accessed 17 December 2019) (in Russian). 
2. Baskaeva J.H. Vypuskaiushchaia kafedra kak osnovnoi element obrazovatelnogo protsessa po podgotovke pedagogicheskikh kadrov $v$ usloviiakh universiteta. PMNO: Poisk. Masterstvo. Novatorstvo. Opyt Materialy regionalnoi nauchno-prakticheskoi konferentsii. Redaktor: Zh.Kh. Baskaeva. [The graduating department as the main element of the educational process for the training of teachers in the University. Pedagogy and methods of primary education: Search. Craftsmanship. Innovation. Experience. Materials of a regional scientific-practical conference. Editor: J.H. Baskaeva]. 2009. pp. 16-24 (in Russian).

3. Bodrova E.V., Davydov V.V., Petrovsky V.A., Sterkina R.B. Opyt postroeniia psikhologo-pedagogicheskoi kontseptsii doshkolnogo vospitaniia. Voprosy psikhologii. [Experience in constructing the psychological and pedagogical concept of preschool education. Psychology]. Issues. 1998. No. 2. Available at: http://www.voppsy.ru/issues/1989/893/893022.htm (accessed 19 December 2019) (in Russian).

4. Gurieva L.K. Evoliutsiia predstavlenii o sotsialnoi otvetstvennosti biznesa. Sovremennye korporativnye strategii i tekhnologii v Rossii. Sbornik nauchnykh statei: V 3 chastiakh. [Evolution of ideas about business social responsibility. Modern corporate strategies and technologies in Russia. Collection of scientific articles: In 3 parts]. Moscow, 2016. pp. 87-92 (in Russian).

5. Gurieva L.K., Nurmagomedov A.A. Sotsialnaia otvetstvennost biznesa: istoki i sovremennye predstavleniia. Gumanitarnye i sotsialno-ekonomicheskie nauki. [Social responsibility of business: the origins and modern ideas. Humanitarian and socioeconomic sciences]. 2016. No. 3 (88). pp. 152-154 (in Russian).

6. Davydov V.V., Kudryavtsev V.T. Razvivaiushchee obrazovanie: teoreticheskie osnovaniia preemstvennosti doshkolnoi i nachalnoi shkolnoi stupenei. Voprosy psikhologii. [Developing education: theoretical basis for the continuity of preschool and primary school levels. Psychology Issues]. 1998. No. 2. Available at: http://www.voppsy.ru/journals_all/issues/1997/971/971003.htm (accessed 19 December 2019) (in Russian).

7. Doshkolnaia pedagogika, pod red. V. I. Yadeshko, F. A. Sokhina. M.: Prosveshchenie, [Preschool pedagogy. Edited by V.I. Yadeshko, F.A. Sokhin. Moscow: Prosveshchenie]. 1978. 429 p. (in Russian).

8. Istoriia doshkolnogo obrazovaniia $v$ Rossii. [The history of preschool education in Russia]. Activityedu.ru Available at: https://activityedu.ru/Blogs/preschool/my-prihodim-vdetskiy-sad/ (accessed 16 December 2019) (in Russian).

9. Istoriia doshkolnoi pedagogiki. M. F. Shabaeva, V. A. Rotenberg, I. V. Chuvashev. pod red. L. N. Litvina. M.: Prosveshchenie, [The history of preschool pedagogy. M. F. Shabaeva, V. A. Rotenberg, I. V. Chuvashev. Edited by L. N. Litvin. Moscow: Prosveshchenie], 1989 (in Russian).

10. Krulecht M.V., Telniuk I.V. Ekspertnye otsenki v obrazovanii: ucheb. posobie dlia stud. fak. doshkolnogo obrazovaniia vyssh. ped. ucheb. zavedenii. M. V. Krulekht, I. V. Telniuk. M.: Izdatelskii tsentr "Akademiia". [Expert assessments in education: Educational Manual for students of pre-school education faculty of high educational institutions. M.V. Krulecht, I. V. Telniuk. Moscow: Publishing Center "Academy"]. 2002. 112 p. (in Russian).

11. Postanovlenie Pravitelstva RF ot 15 aprelia 2014 g. No. 295 "Ob utverzhdenii gosudarstvennoi programmy Rossiiskoi Federatsii "Razvitie obrazovaniia" na 2013 - 2020 gody (s izmeneniiami i dopolneniiami) (utratilo silu). Postanovlenie Pravitelstva RF ot 15 aprelia 2014 g. No. 295 "Ob utverzhdenii gosudarstvennoi programmy Rossiiskoi Federatsii "Razvitie obrazovaniia" na 2013 - 2020 gody. [Resolution of the Govern- 
ment of the Russian Federation, April 15, 2014, No. 295 "On Approval of the State Program of the Russian Federation "Development of Education" in 2013-2020" (as amended and supplemented) is no longer valid. Resolution of the Resolution of the Government of the Russian Federation, April 15, 2014, No. 295 "On Approval of the State Program of the Russian Federation "Development of Education" in 2013-2020"] (in Russian).

12. Prikaz Ministerstva obrazovaniia i nauki Rossiiskoi Federatsii (Minobrnauki Rossii) ot 17 oktiabria 2013 g. № 1155 "Ob utverzhdenii federalnogo gosudarstvennogo obrazovatelnogo standarta doshkolnogo obrazovaniia". [Order of the Ministry of Education and Science of the Russian Federation (Ministry of Education and Science of Russia), October 17, 2013, No. 1155 "On approval of the Federal State Educational Standard for preschool education"]. (in Russian).

13. Federalnyi zakon "Ob obrazovanii v Rossiiskoi Federatsii" No. 273-FZ ot 29 dekabria 2012 goda. [Federal Law "On Education in the Russian Federation" No. 273-Federal Law, December 29, 2012]. (in Russian).

14. Iasli za polmilliona: sozdanie 1 "rebenko-mesta" dlia samykh malenkikh oboidetsia biudzhetu bolee chem $v 500$ tys. rublei. [A nursery for half a million: the creation of one "place for a child" for the smallest will cost for the budget more than 500 thousand rubles]. FinExpertiza.ru Available at: https://finexpertiza.ru/pressservice/researches/2019/yasli-polmilliona/?sphrase_id=9047 (accessed 1 December 2020) (in Russian).

15. Gurieva L.K. New strategic approach to the innovative development of regions. Science almanac of Black Sea Region Countries. 2016. No. 2 (6). pp. 1-4. 